
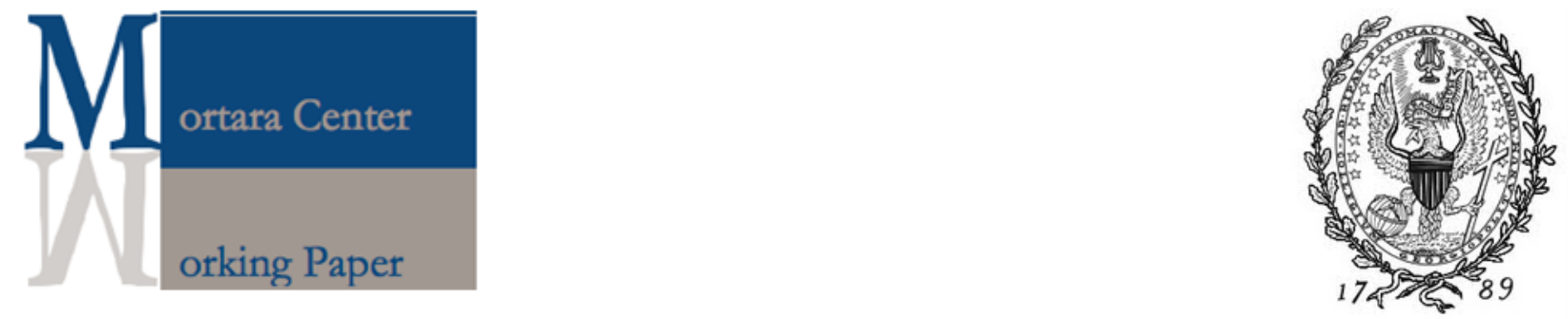

Housing Markets and Current Account Dynamics

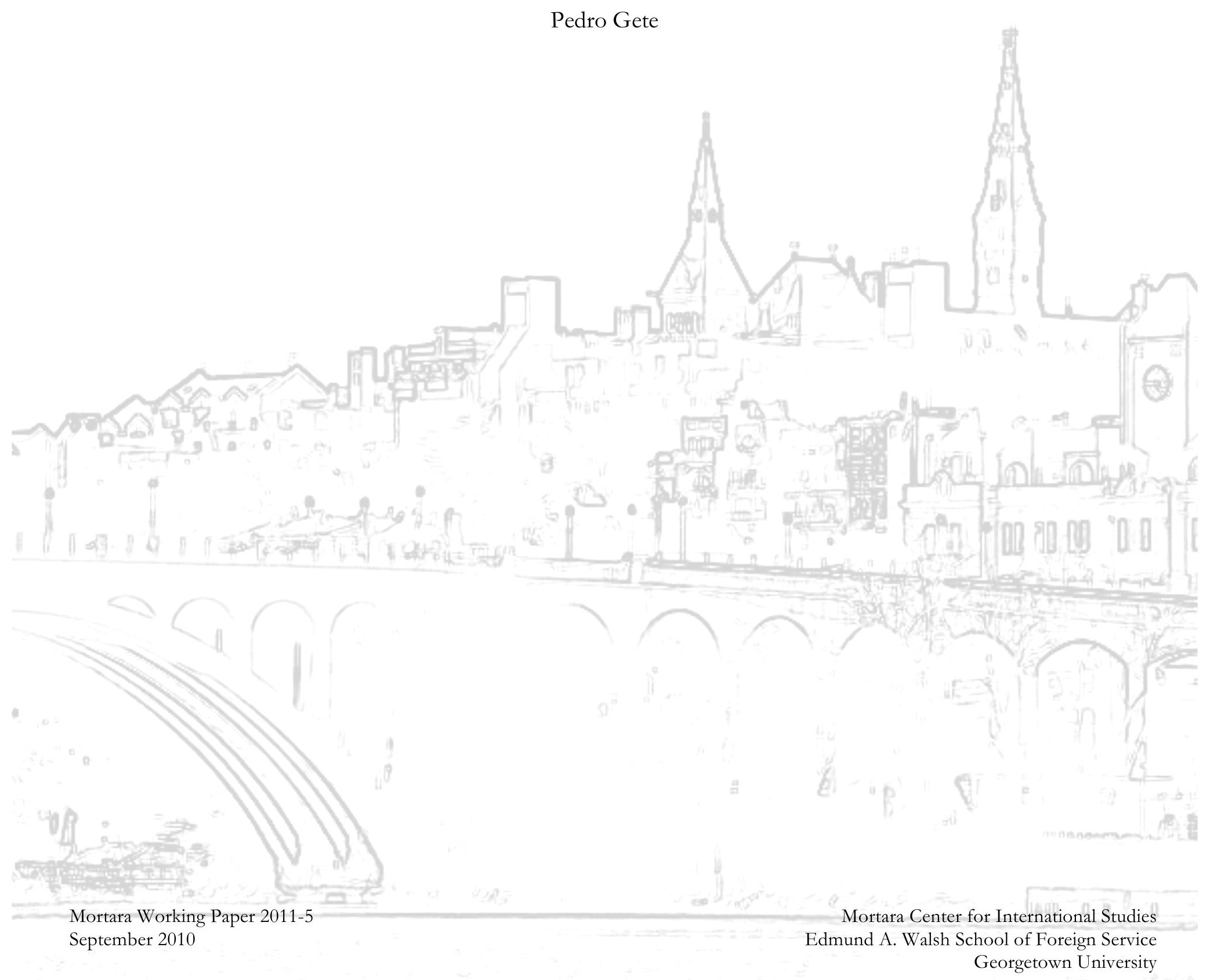




\title{
Housing Markets and Current Account Dynamics*
}

\author{
Pedro Gete ${ }^{\dagger}$
}

September, 2010

First Draft: March 2008

\begin{abstract}
This paper makes two contributions. On the theory side, I show that increases in the demand for housing may generate trade deficits without need for the standard ingredients used by others to model housing (wealth effects or trade in capital goods). Housing is a durable good that must be locally produced. If the desire to smooth consumption across goods is sufficiently strong, countries import tradable goods during periods when more domestic labor is devoted to produce nontradables to smooth consumption between tradables and nontradables. Housing booms are larger if the country can run a trade deficit because the deficit lowers the opportunity cost of building, which is the foregone consumption of tradable goods due to reallocation of labor to the construction sector. On the empirical side, I provide two types of evidence to support the theory. First, I show that using the cross-country dynamics of employment in construction as the explanatory variable, the model generates current account dynamics matching recent global imbalances. Second, I use sign restrictions implied by the model to estimate a vector autoregression. The results for a sample of OECD economies suggest that housing demand shocks matter for current account dynamics through the channel explained before.
\end{abstract}

*I am very grateful to Anil Kashyap, Sam Kortum and Monika Piazzesi for their advice and support. I thank Fernando Alvarez, Maris Goldmanis, Veronica Guerrieri, Robert Lucas, Priscilla Man, Hector Perez, Martin Schneider, Hyun Song Shin, Nancy Stokey, Harald Uhlig and workshop participants at several institutions for helpful comments. Financial support from Banco de España, La Caixa and the University of Chicago is gratefully acknowledged. I also thank the Bank of Spain and the Board of Governors of the Federal Reserve for hospitality while part of this research was undertaken. Christophe Andre, Luca Dedola, Irina Gevorgyan and Kathleen Stephansen were very kind to provide me some data.

${ }^{\dagger}$ Georgetown University and IE Business School. Email: pg252@georgetown.edu 


\section{Introduction}

What explains recent current account dynamics? This question has attracted a lot of attention because in the decade previous to the recent financial crisis, the U.S. and some other developed economies run large and persistent current account deficits, often referred to as "global imbalances". This paper makes a theoretical and an empirical contribution to the debate. On the theory side, I show that shocks to the demand for housing generate trade deficits without need for the standard ingredients used by others to model housing (wealth effects or trade in capital goods). Countries import tradable goods during periods when more domestic labor is devoted to produce nontradables to smooth consumption between tradables and nontradables. Housing booms are larger if the country can run a trade deficit because the deficit lowers the opportunity cost of building, which is the foregone consumption of tradable goods due to reallocation of labor to the construction sector. On the empirical side, I provide two types of evidence to support that cross-country heterogeneity in housing demand help to explain the global imbalances through this theoretical channel.

Heterogeneity in housing demand is an unexplored explanation for the global imbalances that is appealing for three reasons ${ }^{1}$. First, as I document in Section 2, there are large cross country differences in housing dynamics and these differences strongly correlate with current account dynamics (especially for housing quantities, such as labor share in construction or value added by this sector). Alternative theories of the global imbalances have problems explaining the substantial heterogeneity in the current account dynamics of developed and emerging economies $^{2}$. Second, a large part of the current account deficits were financed through sales of mortgage related products (Shin 2008 discusses the U.S. case, The Telegraph 2008 the Spanish case). It is unclear why, in the absence of shocks increasing the demand for funds from the housing sector, foreigners should express such a strong preference for mortgage products, especially when in most countries they contained low quality subprime assets not backed up by public guarantees. Finally, housing specific factors may have important aggregate implications

\footnotetext{
${ }^{1}$ To my knowledge only Matsuyama (1990), Punzi (2008), Aizenman and Jinjarak (2009) and Laibson and Mollerstrom (2010) have related housing and current account dynamics. Aizenman and Jinjarak (2009) is a regression study that documents a strong positive association between current account deficits and the appreciation of real estate prices without providing evidence on causation. Matsuyama (1990) is a theoretical study of the current account consequences of income effects on residential investment. Punzi (2008) explains the relationship with a two country version of Iacoviello (2005) model of housing wealth effects. Laibson and Mollerstrom (2010) also focus on aggregate wealth effects.

${ }^{2}$ For example, theories based on differences in financial development or in income growth face the problem that several countries similar across these dimensions had very different current account patterns (Eichengreen 2006, Gruber and Kamin 2009, Roubini 2006). Models focused on U.S.-specific factors cannot explain why large and persistent deficits have not being a U.S. specific pattern, i.e., several other developed economies have had a similar persistent downward trend, with deficits reaching similar levels of GDP.
} 
because the housing sector is large. For example, in the U.S. from 2001 to 2006, the housing contribution to total employment growth was at least $28 \%$ from residential construction and at least $41 \%$ when mortgage finance, real estate agents, construction materials etc. are included (The Economist 2005; Roubini 2006b).

The two standard ways to connect housing and the trade balance are trade on investment goods (trade deficits generated by investment booms), and aggregate wealth effects of housing on consumption. The model that I present does not have aggregate wealth effects, nor capital goods. Instead, it focuses on consumption smoothing across goods to link residential activity to current account dynamics. This channel is not mentioned in the literature but is appealing for two empirical reasons. First, there is a lack of consensus on the magnitude and sign of aggregate housing wealth effects (see, for discussion, Buiter 2008, Muellbauer 2007 and Kiyotaki et al. 2007; Congressional Budget Office 2007 surveys recent U.S. studies). Second, in the U.S. net imports of capital goods account for a smaller fraction of the deficit dynamics than do net imports of consumption goods. Net imports of consumer goods are twice the net imports of capital goods and their downward trend has accelerated since the mid 1990s. This fact suggests that consumption smoothing may be a more important driving force of trade deficits that capital dynamics. Moreover, most of the capital employed to build houses is not tradable. Burstein et al. (2004) report that the share of construction gross output attributable to tradable materials was at most 24\% in France in 1995, 19\% in the U.K. in 1998 and $31 \%$ in the U.S. in 1997.

I set up a simple model to illustrate why consumption smoothing across goods and the opportunity costs associated with building are enough to generate trade deficits after an increase in housing demand. There are two goods in the model, houses and tradable goods. Houses are nontradable and durable. Each country has a fixed supply of labor that can allocate to produce either tradable goods or new houses. The tradable good is identical for both countries, thus there is only intertemporal trade. I assume exogenous shifts of the aggregate preferences towards housing. These shifts increase the demand for housing relative to other goods. To increase the quantity consumed, the economy has to move labor from producing tradable goods to constructing houses. This labor reallocation implies the opportunity cost of building new houses, which is the foregone production of tradable goods. Trade deficits lower this cost because they decouple consumption from production. By importing consumer tradables the economy can reduce its production of tradables while still consuming them. Thus trade deficits allow for smooth consumption across goods while building more at a faster pace. Hence housing booms are larger when the economy can run a trade deficit.

On the empirical side, the contribution of this paper is to show that cross-country het- 
erogeneity in housing demand helps to explain the global imbalances through the theoretical channel discussed before. This paper does not study the causes of the heterogeneity in housing dynamics $^{3}$; this is taken as given and captured via exogenous housing demand shocks (shocks to the aggregate marginal rate of substitution between housing and tradables). Several papers provide housing demand arguments that could explain the cross-country heterogeneity. We can think of them as micro-foundations for the demand shocks of this paper: bubbles, demographic changes, deregulation or innovation in mortgage markets, loosened lending standards, public policies to increase homeownership or preference changes between single and multi-unit houses ${ }^{4}$. Moreover, DSGE models of housing attribute a significant part of the recent housing dynamics to domestic preference shocks (Aspachs-Bracons and Rabanal 2010a; Iacoviello and Neri 2010).

I provide two types of evidence to support my theory. First, in a parameterized version of the model using the housing variables as explanatory variables, the model predicts global imbalances similar to those observed in the data. Second, the model provides sign restrictions to identify housing demand shocks that affect the economy through the consumption smoothing channel: conditional on a positive shock, the correlation between the shock, interest rates, housing prices, employment in construction and residential investment is positive. Moreover, the conditional correlation of the shock with tradable consumption is negative. As I discuss in Section 6 these sign restrictions differ from those implied by alternative theories. For example, the "savings glut hypothesis", or interest rate shocks from lower risk premiums, predict negative comovement of housing and interest rates (Caballero et al. 2008). Sector specific technology shocks do not imply increases in both house prices and residential investment. Neutral technology shocks or discount factor shocks (a standard way to generate aggregate wealth effects) do not generate negative comovement of housing and tradable consumption for several periods because if both housing and tradable consumption are normal goods then higher income, or higher impatience, increase households' demand for both goods, thus generating positive comovement (AspachsBracons and Rabanal 2010b, Punzi 2008). Using these sign restrictions I estimate a vector autoregression for a sample of OECD economies. The results suggest that housing shocks and the consumption smoothing channel matter for the dynamics of the trade balance.

The paper proceeds as follows. Section 2 documents some facts on housing and current account dynamics. Section 3 describes the model. In Section 4, to illustrate the essence of

\footnotetext{
${ }^{3}$ This is still an open question. See Andre (2010), Glaeser et al. (2010) and Mayer and Hubbard (2008) for recent discussion of alternative explanations.

${ }^{4}$ As additional evidence, Doms and Krainer (2007) examine data from American Housing Surveys between 1997 and 2005 and report a substantial increase in the share of household income devoted to housing and the propensity for households to own their homes. They find that these results hold true across all income quintiles, ages and education levels. They do not depend on market location; that is, the higher expenditures do not simply reflect higher house prices, but a general increase in the demand for housing.
} 
the mechanism I first characterize the equilibrium of a two period model with full housing depreciation, then I parameterize the model of Section 3 and perform impulse response analysis. Section 5 shows how the model can account for recent patterns of global imbalances. Section 6 estimates a vector autoregression using the sign restrictions implied by the model. Section 7 concludes.

\section{Motivating facts}

In this section I present three types of evidence motivating my model. First, over the period of the global imbalances there has been substantial heterogeneity in the current account dynamics of developed economies with several countries running large and persistent deficits. Second, over this period there is a strong negative cross-country correlation between housing and current account dynamics. Third, net imports of consumer goods are twice the net imports of capital goods and their downward trend has accelerated since the mid 1990s.

\subsection{Two facts about current account dynamics}

First, large and persistent deficits are not a U.S.-specific pattern, as Figure 1 illustrates. Several other developed economies have had a persistent downward trend similar to that of the United States, with deficits reaching similar levels of GDP.

Second, there has been substantial heterogeneity in the current account dynamics of developed economies. Table 1 reports this ${ }^{5}$ : while the countries on the left panel moved into surpluses, those in the right panel moved into deficits. The heterogeneity within Europe is especially interesting, because the European Union as a whole had a nearly balanced current account $^{6}$.

\footnotetext{
${ }^{5}$ In the U.S. and most of the OECD countries the housing boom lasted from around 1994 to 2006 (Andre 2010)

${ }^{6}$ There is also a puzzling pattern among emerging economies (IMF 2008). Most of Emerging Asia moved into current account surpluses while emerging Europe moved into current account deficits. In this paper I only used data from the OECD. Anecdotal evidence suggests that emerging markets also followed the patterns reported in Figure 2.
} 


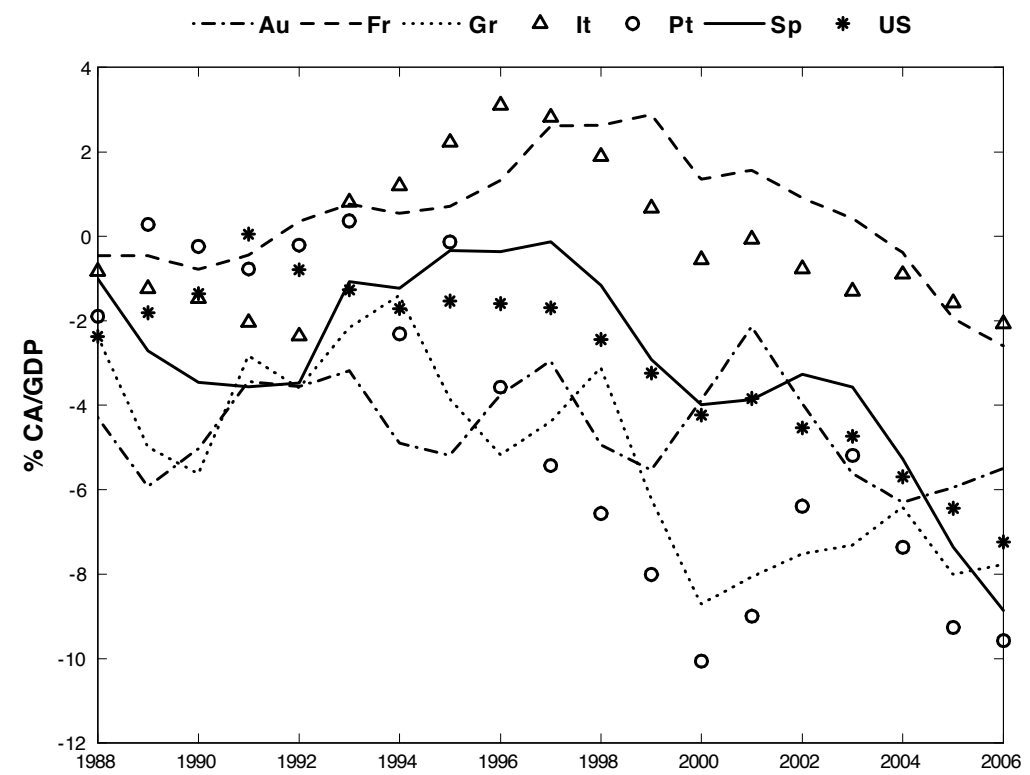

Fig. 1. Ratio of current account to GDP for Australia, France, Greece, Italy, Portugal, Spain, and the U.S.

\section{Table 1: Current account as \% OF GDP}

Rising surpluses

\begin{tabular}{llllllll}
\cline { 6 - 7 } \cline { 5 - 6 } & & $\underline{1994}$ & $\underline{2006}$ & & & $\underline{1994}$ & $\underline{2006}$ \\
Austria & -1.47 & 1.9 & & Australia & -4.9 & -5.49 \\
Germany & -1.41 & 4 & & France & 0.54 & -2.59 \\
Japan & 2.75 & 3.9 & & Ireland & 2.69 & -1.04 \\
Korea & -0.95 & 1.6 & & Italy & 1.18 & -2.07 \\
Netherlands & 4.75 & 9.52 & & Spain & -1.23 & -8.86 \\
Switzerland & 6.22 & 13.5 & & Portugal & -2.31 & -9.58 \\
Canada & -2.3 & 3.34 & & UK & -0.99 & -2.45 \\
Sweden & 1.13 & 6.7 & & USA & -1.71 & -7.24 \\
\hline
\end{tabular}




\subsection{Housing and current account dynamics}

Global imbalances grew almost monotonically from the mid 1990s to the mid 2000s. OECD data show a strong negative cross-country correlation between housing and current account dynamics over this period. The correlations are particularly strong for variables related to the quantity of housing, such as the share of labor employed in construction or the value added by this sector, and are weaker for price variables, such as the real price of housing. Figure 2 illustrates these facts for a sample of seventeen OECD countries between 1994 and 2006. For most countries these are the dates during which housing variables grew monotonically (Andre 2010). Given the trend behavior of the time series, I concentrate on the changes between these two dates. This provides a good idea of the size of the changes.

The three panels of Figure 2 plot on the vertical axis the change in percentage points in the current account to GDP ratio. The top, middle and bottom panels plot respectively on the horizontal axis the percentage change in the labor share in construction, the percentage change in the share of value added by the construction sector and the percentage change in an index of real housing prices. Countries that experienced housing booms also had larger current account deficits. The scatterplots also show substantial heterogeneity in the behavior of housing markets among OECD countries. The model in this paper uses this heterogeneity to explain the differences in current account balances reported in Table 1.

\subsection{The importance of consumption goods in the U.S. trade deficit}

Net imports of capital goods account for a smaller fraction of the deficit dynamics than do net imports of consumption goods. This is shown in Figure 3, which decomposes the time series for the U.S. trade balance in goods in different groups: autos, capital goods, consumption goods and energy. Net imports of consumer goods are twice the net imports of capital goods and their downward trend has accelerated since the mid 1990s. This fact suggests that consumption smoothing may be a more important driving force of trade deficits than capital dynamics.

\section{The Model}

In this section I describe a simple model that is consistent with the previous facts: increases in the demand for housing will imply trade deficits through net imports of consumption goods to smooth consumption. 

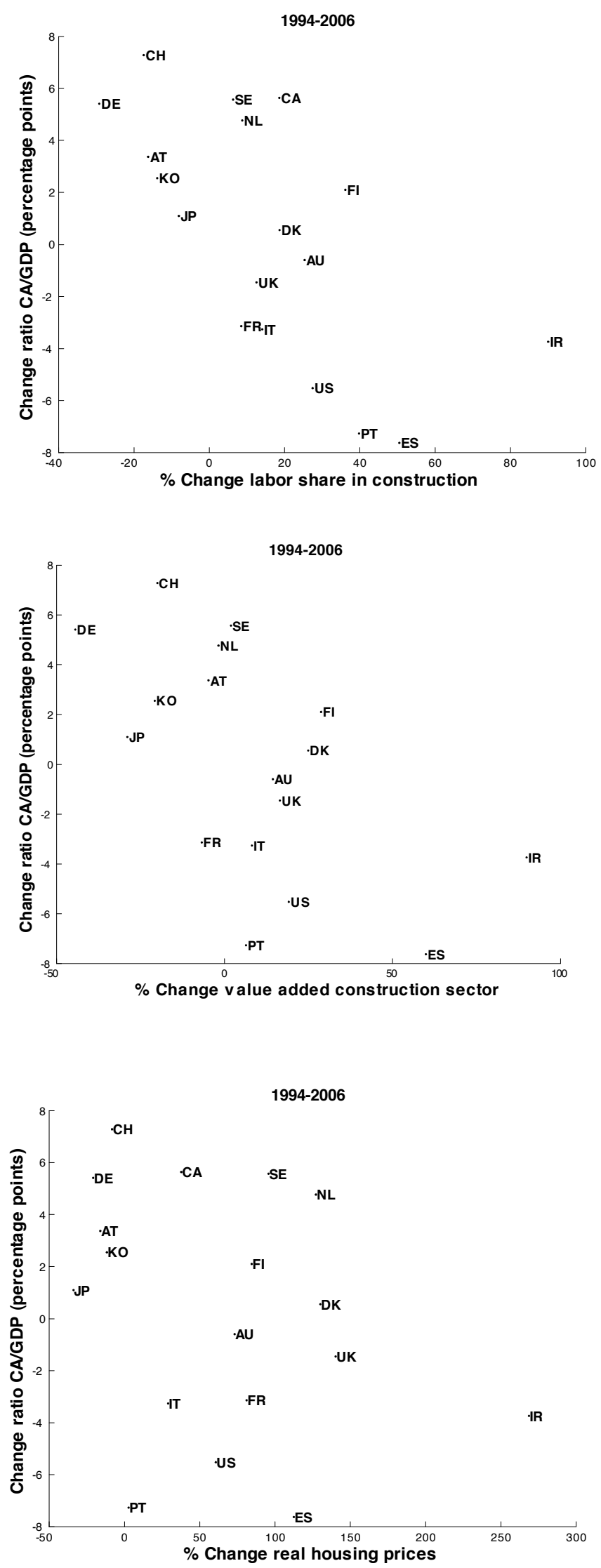

Fig. 2. Percentage changes in labor share in construction, in value added by construction, and in real housing prices versus the percentage-points change in the ratio of the CA to GDP 


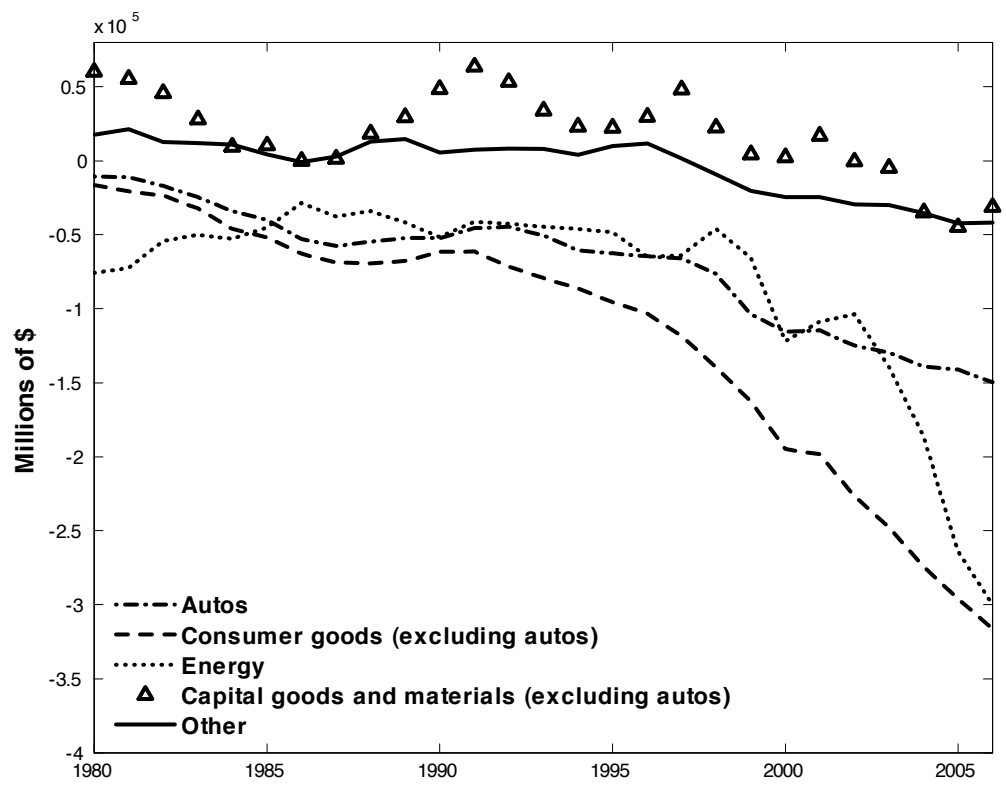

Fig. 3. Decomposition of the U.S. trade balance in goods by type of good

\subsection{Technology and preferences}

There are two countries with the same preferences and technologies. Labor $(n)$ is the only production input and it can be used to produce new houses $\left(y_{h}\right)$ or tradable goods $\left(y_{c}\right)$. The tradable good is identical for both countries, hence there is only intertemporal trade. The production functions in country $i$ are

$$
\begin{aligned}
& y_{i h t}=A n_{i h t}^{\alpha} \\
& y_{i c t}=n_{i c t}^{\alpha}
\end{aligned}
$$

where $\alpha \in(0,1)$.

Houses $(h)$ are durable and nontradable. They give a flow of housing services proportional to the stock. Houses can be consumed in the same period as they are built (in the next section I will calibrate the model to a five year period). The stock of houses depreciate geometrically at rate $\delta_{h} \in(0,1)$, and its law of motion is

$$
h_{i t}=\left(1-\delta_{h}\right) h_{i t-1}+y_{i h t}
$$

Labor is mobile between both sectors with no adjustment costs, but it cannot move between 
countries. Feasibility implies that world production of tradable goods must equal world consumption of tradable goods. Moreover, labor allocated to each sector must sum to the total labor endowment $\left(n_{i}\right)$. The resource constraints are

$$
\begin{aligned}
\sum_{i} c_{i t} & =\sum_{i} y_{i c t} \\
n_{i h t}+n_{i c t} & =n_{i}
\end{aligned}
$$

There is an infinitely lived representative household in each country who enjoys consumption of housing and tradable goods without any home bias. They supply labor inelastically in their home country. The representative household in country $i$ maximizes utility over consumption of housing services $\left(h_{i t}\right)$ and tradable goods $\left(c_{i t}\right)$

$$
\sum_{t=0}^{\infty} \beta^{t} u\left(c_{i t}, h_{i t}\right)
$$

I assume the standard constant relative risk aversion functional form over a constant elasticity of substitution aggregator of housing services and tradable consumption

$$
u\left(c_{i t}, h_{i t}\right)=\frac{\left(\left(\left(1-\theta_{i t}\right) c_{i t}^{\frac{\varepsilon-1}{\varepsilon}}+\theta_{i t} h_{i t}^{\frac{\varepsilon-1}{\varepsilon}}\right)^{\frac{\varepsilon}{\varepsilon-1}}\right)^{1-\frac{1}{\sigma}}}{1-\frac{1}{\sigma}}
$$

where $\sigma$ is the elasticity of intertemporal substitution (IES) as well as the inverse of the coefficient of relative risk aversion, $\varepsilon$ is the static or intratemporal elasticity of substitution between housing and tradable consumption (SES), and $\theta_{i t} \in(0,1)$ is a country-specific parameter that controls the share of consumption of housing services in total expenditure.

\subsection{Equilibrium}

Since there are no distortions, the set of competitive equilibria can be traced out by solving for the Pareto optima. Thus, a competitive equilibrium is the solution to the problem of a world planner who maximizes the weighted utility of both countries

$$
\sum_{t=0}^{\infty} \sum_{i} \lambda_{i} \beta^{t} u\left(c_{i t}, h_{i t}\right)
$$


subject to equations $(1)-(5)$ for country weights $\lambda_{i}$. I focus on the equilibrium associated with $\lambda_{1}=\lambda_{2}=1$. These weights give the same allocations that arise in a competitive equilibrium in which the representative household in country $i$ has no initial debts, owns the initial stock of houses in country $i$, and all the labor income in country $i$.

If we denote by $\varphi_{i t}$ the Lagrange Multiplier associated with (3), the FOCs of the problem are

$$
\begin{aligned}
u_{c}\left(c_{1 t}, h_{1 t}\right) & =u_{c}\left(c_{2 t}, h_{2 t}\right) & & \\
\varphi_{i t} & =u_{h}\left(c_{i t}, h_{i t}\right)+\beta\left(1-\delta_{h}\right) \varphi_{i t+1} & & i=1,2 \\
\varphi_{i t} \frac{y_{i h t}}{n_{i h t}} & =u_{c}\left(c_{i t}, h_{i t}\right) \frac{y_{i c t}}{n_{i c t}} & i & =1,2
\end{aligned}
$$

Equation (8) implies that both countries must value equally one extra unit of the tradable good in equilibrium. Equation (9) captures that the marginal utility of the durable good expands over several periods. Finally, equation (10) says that at any interior equilibrium each country must be indifferent between allocating labor to one sector or to the other, i.e. the marginal utility of housing multiplied by the labor productivity in that sector must equal the marginal utility of tradable consumption multiplied by the labor productivity in the tradable sector.

\section{Increases in Housing Demand and Trade Deficits}

This section studies the effects of transitory shocks that increase the preference for housing relative to tradable goods. I first characterize the equilibrium of a two period model with full housing depreciation. This exercise illustrates the key ingredients of the mechanism: the nontradability of housing and a low intratemporal elasticity of substitution between housing and tradable consumption. I then confirm the results by performing impulse response analysis in a multiperiod version of the model.

\subsection{A two period model with no durable good}

In this subsection I consider a two period version of the model with full housing depreci-

ation, $\delta_{h}=1$. When $\frac{N_{1}}{N_{2}}$ is very small we can think of country 1 as a small open economy, i.e. shocks in country 1 have no effect on the world interest rate $(R)$. For the rest of the subsection I focus on country 1 and drop the notation $i$. I will compare the differences between the equi- 
librium in a closed economy and that in a small open economy after an unanticipated change in the share of housing in the first period utility $\left(\theta_{1}\right)$. In the closed economy the interest rate is endogenous while in the small open economy it is exogenous.

Also, to reduce notation I assume that the household in country 1 is both the producer and the consumer. Thus, in the competitive equilibrium she maximizes

$$
U\left(c_{1}, h_{1}, c_{2}, h_{2}\right) \equiv u\left(c_{1}, h_{1}\right)+\beta u\left(c_{2}, h_{2}\right)
$$

subject to the intertemporal budget constraint in terms of tradable goods

$$
c_{1}+\frac{c_{2}}{R}=y_{c 1}+\frac{y_{c 2}}{R}
$$

and to equations (1), (2), (5) and

$$
h_{t}=y_{h t} \quad \text { for } t=1,2
$$

The FOCs are the Euler equation and the equalization of the marginal rate of substitution with the marginal rate of transformation

$$
\begin{aligned}
u_{c}\left(c_{1}, h_{1}\right) & =\beta R u_{c}\left(c_{2}, h_{2}\right) \\
u_{h}\left(c_{t}, h_{t}\right) \frac{y_{h t}}{n_{h t}} & =u_{c}\left(c_{t}, h_{t}\right) \frac{y_{c t}}{n_{c t}} \quad \text { for } t=1,2
\end{aligned}
$$

In a closed economy there is not an option to transfer tradable consumption across periods, so production and consumption of tradable goods must be equal in every period

$$
c_{t}=y_{c t} \quad \text { for } t=1,2
$$

The equilibrium of the closed economy in period 1 is characterized by

$$
\frac{u_{h}\left(y_{c 1}, y_{h 1}\right)}{u_{c}\left(y_{c 1}, y_{h 1}\right)}=\frac{n_{h 1}}{y_{h 1}} \frac{y_{c 1}}{n_{c 1}}
$$

The upper left panel of Figure 4 graphs this condition. The left hand side of equation (17) is the slope of the indifference curve, which, at the initial equilibrium point $\mathrm{A}$, is tangent to the Frontier of Possibilities of Production (FPP), whose slope is the right hand side of equation (17).

An unexpected increase in $\theta_{1}$ decreases the slope of the indifference curves as graphed in the 
upper right panel of Figure 4. The household now likes housing more, hence she asks for more tradable goods per unit of housing. The shift of the indifference curves moves the equilibrium from point A to point B, where consumption of housing services is higher $\left(\tilde{h}_{1}^{c}>h^{*}\right)$ and consumption of tradable goods lower $\left(\tilde{c}_{1}^{c}<c^{*}\right)$. There are two reasons why consumption of tradable goods is lower. One comes directly from the preference shock; the household now likes tradable goods relatively less, hence she consumes less of them. The second comes from the opportunity cost of building; to increase the consumption of housing services the country needs to move along the FPP, reducing production of tradable goods.

The closed economy is a sequence of static problems. An increase in $\theta_{1}$ does not alter second period variables. The unexpected increase in $\theta_{1}$ moves the closed economy equilibrium from point $\mathrm{A}$ to point $\mathrm{B}$, but $c_{2}^{c}$ remains at steady state value $c^{*}$. I am interested in the case when the marginal utility of tradable consumption in the first period increases after an increase in $\theta_{1}$, i.e., when even if the preference shock makes tradable goods less appetizing, their marginal value in period 1 increases because the household likes to smooth consumption across goods. In this case the preference shock would increase the autarky interest rate, which from equation (14) can be defined as

$$
R^{a u t} \equiv \frac{u_{c}\left(\tilde{c}_{1}^{c}, \tilde{h}_{1}^{c}\right)}{\beta u_{c}\left(c^{*}, h^{*}\right)}
$$

This is what the lower right panel of Figure 4 plots. The preference shock increases the marginal utility of a tradable good in period 1. To ensure that the closed economy does not transfer tradable goods across periods, the interest rate, which is the slope of the intertemporal budget constraint, increases.

For preferences (7) the marginal utility of tradable consumption in the first period is

$$
\begin{aligned}
u_{c}\left(c_{1}, h_{1}\right) & =\left(1-\theta_{1}\right) C_{1}^{\frac{1}{\varepsilon}-\frac{1}{\sigma}} c_{1}^{\frac{-1}{\varepsilon}} \\
C_{1} & \equiv\left(\left(1-\theta_{1}\right) c_{1}^{\frac{\varepsilon-1}{\varepsilon}}+\theta_{1} h_{1}^{\frac{\varepsilon-1}{\varepsilon}}\right)^{\frac{\varepsilon}{\varepsilon-1}}
\end{aligned}
$$

When the SES $(\varepsilon)$ equals the IES $(\sigma)$ preferences are separable and $u_{c}\left(c_{1}, h_{1}\right)$ only depends on the SES. The lower the SES, the less willing the household is to substitute housing and tradable consumption within the period. As plotted in the upper right panel of Figure 4, the unexpected increase in $\theta_{1}$ increases $h_{1}$ and decreases $c_{1}$. This result holds for any parameter value consistent with the concavity of the FPP and the convexity of the indifference curves. The more concave the FPP, the higher the drop in $c_{1}$, since more resources need to reallocate to produce an extra unit of housing. In addition, the lower the SES, the more likely that the decrease in $c_{1}$ increases $u_{c}\left(c_{1}, h_{1}\right)$ and autarky interest rates. Low SES households dislike 
unbalanced consumption across goods, thus an extra unit of the tradable good is valued more when building houses forces the economy to reduce production and consumption of tradables.

When preferences are not separable $(\varepsilon \neq \sigma)$, equation (19) shows that there may be a tradeoff between intertemporal and intratemporal smoothing. Smoothing across goods may imply unbalanced consumption across periods, something disliked by agents with low IES. Depending on the value of the parameters it may happen that the increase in $\theta_{1}$ decreases the marginal utility of tradable consumption. From now on I will assume that the parameters satisfy the conditions for $u_{c}\left(\tilde{c}_{1}^{c}, \tilde{h}_{1}^{c}\right)$ to increase as $\theta_{1}$ increases.
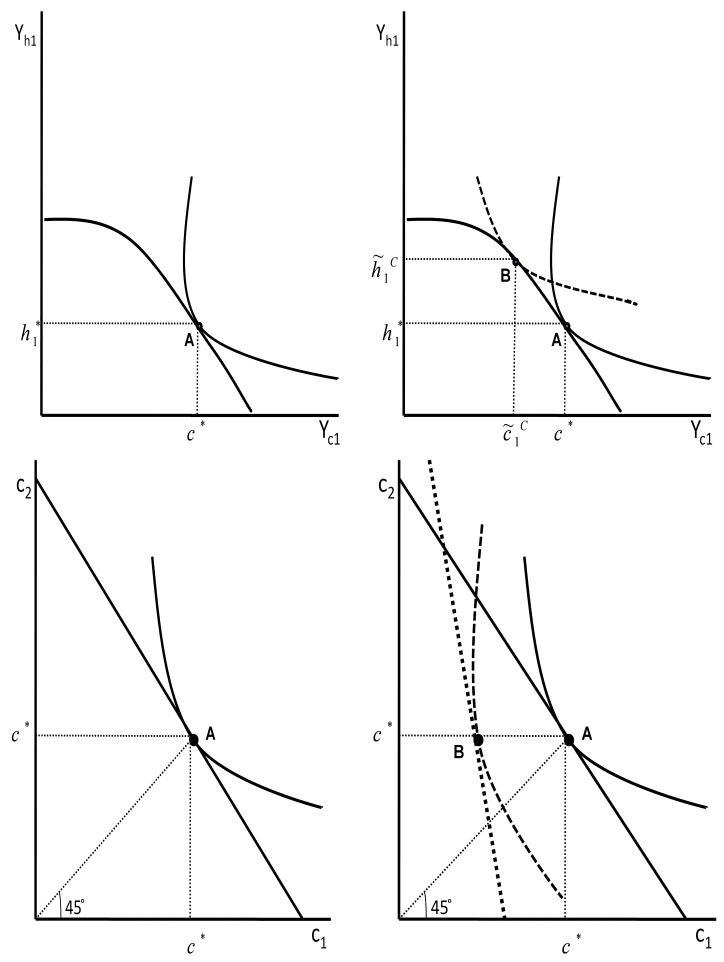

Fig. 4. The two period model with no durable good: the closed economy

If in the small open economy, or in a two country model, an increase in $\theta_{1}$ does not increase interest rates to the new autarky level, then the country will borrow and run a trade deficit. The trade deficit allows better consumption smoothing across goods in the open economy. Figure 5 depicts this case. The increase in $\theta_{1}$ shifts the marginal rate of substitution as in the closed economy, but for the small economy the interest rate is exogenous and does not change. The slope of the intertemporal budget constraint remains the same, although the budget constraint shifts because both $Y_{c 1}$ and $Y_{c 2}$ will change. Now the economy does not have to move to point 
B, where consumption equals production. The small economy can instead consume at the point $\mathrm{C}$ while producing at the point $\mathrm{D}$ of the upper right panel of Figure 5 if it respects its intertemporal budget constraint (12); FOC (15) only requests that the slope of the indifference curve is the same at both points. Point $\mathrm{C}$ was not available for the closed economy because it implies a transfer of tradable goods across periods. Interest rates raised to prevent this.
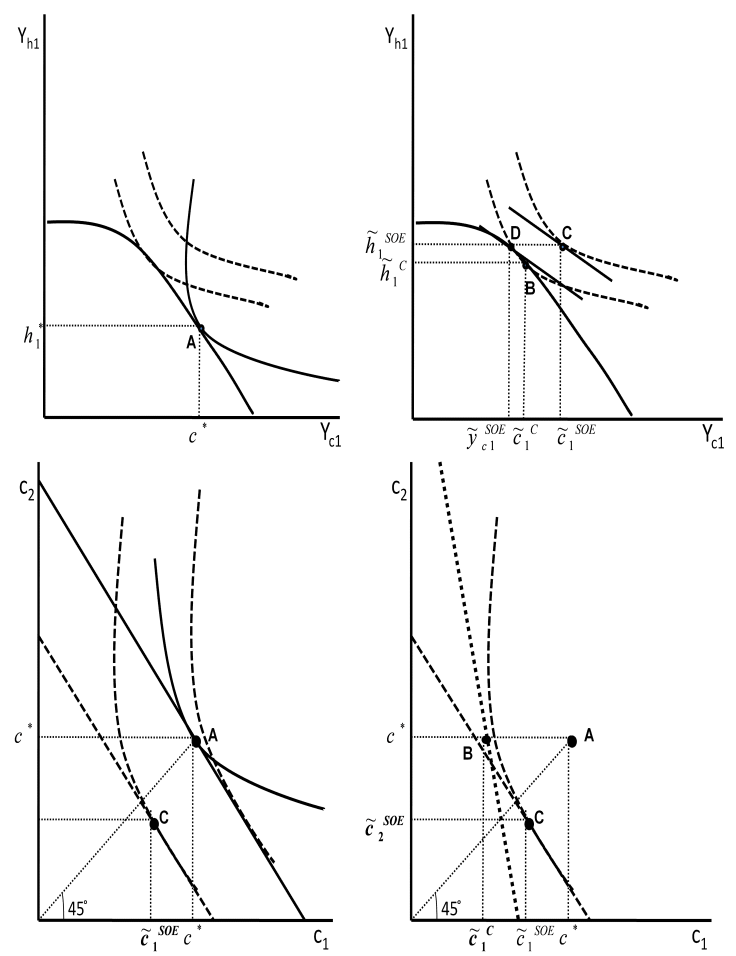

Fig. 5. The two period model with no durable good: the small open economy

\subsection{Impulse responses in the full model}

The full model of section 3 does not have a closed form solution. In this subsection I show that for a reasonable parametrization, increases in the demand for housing generates trade deficits through net imports of consumption goods to smooth consumption.

I calibrate a world with two symmetric countries $(i=1,2)$ that face different housing shocks. If both countries face shocks of the same size, they are like closed economies. I assume that both countries have the same population size. This allows me to study how domestic shocks affect the trade partners. The length of a period in the model is five years. There are two sets of parameters to choose: 
1. Preference parameters: I set the unconditional mean of the share of housing in the economy $\left(\theta_{i}^{*}\right)$ to 0.2 . This number is consistent with recent data on the weight of the housing sector in the U.S. economy ${ }^{7}$ (The Economist 2005, Roubini 2006b). As discussed in Section 4.1, for the mechanism to work there is a trade-off between the intertemporal elasticity of substitution $(\sigma)$ and the intratemporal elasticity between housing and tradable goods $(\varepsilon)$. There is no consensus in the literature about the value of these parameters. Most of the real business cycle literature assumes $\sigma=\frac{1}{2}$, which under CRRA preferences implies a value for risk aversion of 2 . I will follow this literature but many asset pricing models defend other values $^{8}$. Concerning $\varepsilon$, I do not know of any papers that provide estimates of this parameter, although some papers have estimated related concepts. For example Tesar (1993) estimates the elasticity between traded and nontraded goods to be 0.44. Davis and Heathcote (2005) argue for a unitary elasticity of substitution between non-housing consumption (without distinguishing between tradables and nontradables) and housing. Piazzesi et al. (2007) claim that the elasticity between non-housing consumption and housing is not one but it may be not be far from it (they provide estimates based on Euler equations for excess returns that range between 1.17 and 1.24 but come with huge standard errors). Davidoff and Yoshida (2008) obtain estimates for this elasticity ranging from 0.4 to 0.9 and Kahn (2008) provides evidence based on both aggregate and microeconomic data that is less than one. I use $\varepsilon=0.9$.

2. Technology parameters: I assume the same labor share across sectors and set it to the standard $\alpha=0.67$. I choose the discount factor to match a steady state interest rate of $10 \%$. For the depreciation of the stock of houses, I use the five year equivalent of $2 \%$ annual depreciation, $\delta_{h}=0.1$, which is consistent with the BEA (2004) report that annual depreciation rates for one-to-four-unit residential structures are between $1.1 \%$ and $3.6 \%$. Concerning the scale parameters I normalize $n$ to 1 so $n_{h}$ is the labor share in construction. I set A to be $1 / 30$, which gives a construction labor share of $14 \%$ in a steady state with zero trade balance.

To illustrate the mechanics of the model, in period zero I give an unanticipated housing preference shock to country 1 that increases $\theta_{1}$ from its unconditional mean $\theta^{*}$ to $\theta_{1}=0.5$. The goal is not to be quantitative but to give a large enough increase to clearly show the mechanics of the model. If country 2 had a shock of the same size, then both countries would behave exactly as if they were closed economies.

\footnotetext{
${ }^{7}$ It is also in line with Davis and Ortalo-Magne (2010) that estimate the housing expenditure share in the U.S. to be close to 0.25 from 1980 to 2000. Davis and Ortalo-Magne (2010) used renter data to compute expenditure shares for housing and found this share to be stable over that period. Doms and Krainer (2007) examined data on the share of household income devoted to housing by homeowners and report a substantial increase between 1997 and 2005.

${ }^{8}$ See Guvenen (2006) and Davidoff and Yoshida (2008) for recent surveys.
} 
Figure 6 shows the results. After a housing preference shock, the country wants to consume more housing services. Since these are not tradable, the country needs to build more houses. This implies reallocating labor to the construction sector and sacrificing production of tradable goods. This happens both in the open and in the closed economy. The open economy can decouple consumption decisions from production decisions because it can import tradables for consumption. But the closed economy cannot. In the closed economy, building more houses requires reducing tradable consumption. This is an implicit adjustment cost, because housing services and tradable consumption are complements the household wants to smooth consumption across goods. The open and closed economies react differently to the same housing shock. Both reduce tradable consumption and reallocate labor towards construction, but the open economy runs a trade deficit importing tradables for consumption. This enables a smaller reduction in tradable consumption and increased consumption of housing services. These dynamics are shown in Figure 6.

Two prices govern the competitive equilibrium of this economy: $i$ ) the relative price of housing services in terms of consumer tradables; and $i i$ ) the real interest rate, the price of one unit of the tradable good today in terms of tradable goods tomorrow. The housing shock implies an increase in the demand for housing. This translates into higher housing prices and construction. Although the shock reduces preferences for tradable goods, tradables are valuable because they allow smoothing of foregone consumption due to reallocation of labor to housing. The increase in intertemporal demand requires interest rates to rise. In an open economy, interest rates jump less than in a closed economy because country 2, by financing a trade deficit, helps to satisfy demand for tradables in country 1.

Housing booms are larger in open economies that can run trade deficits. This prediction is confirmed by recent housing dynamics in the OECD. Girouard et al. (2006) document more generalized housing upswings across OECD countries in recent years than in the past. These upswings coincided with the OECD opening to trade with non-OECD economies and starting to run an aggregate trade deficit.

The model is a representative agent model and housing is not tradable. There are no wealth effects from a housing shock. But this does not preclude the housing boom from causing a trade deficit. Trade deficits and housing reactions are quantitatively large in the model. This happens because there are no frictions and because markets are complete. Finally, the absence of frictions allows the economy to build the desired housing stock in a couple of periods. 

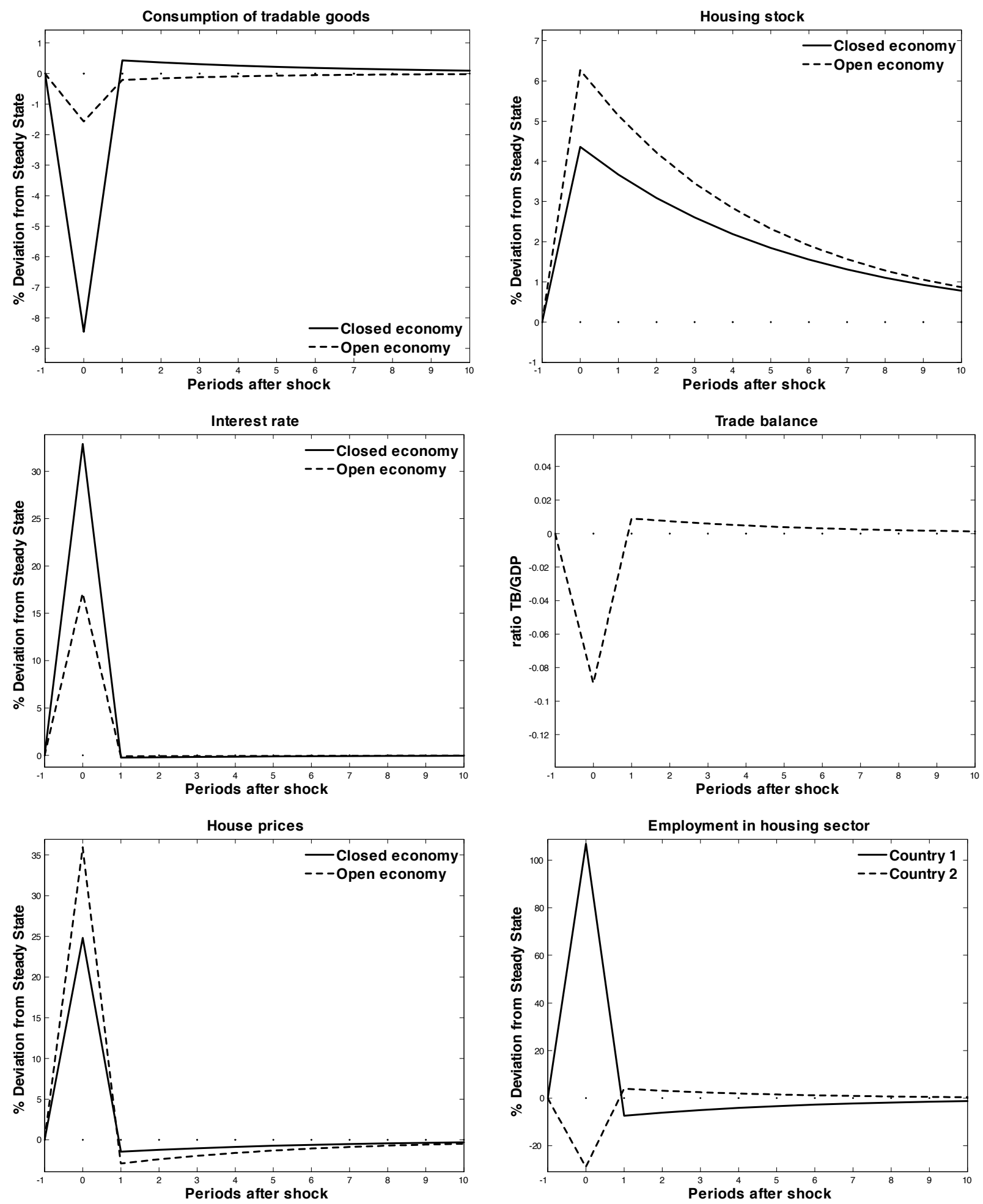

Fig. 6. Theoretical responses to an unexpected housing shock in country 1 


\section{The Model and The Global Imbalances}

The model discussed before is deliberately simple to highlight a mechanism ignored in the housing literature. Simplicity comes at the expense of the quantitative abilities of the model. However, in this section I show how the model can rationalize the global imbalances displayed in Figure 2 using the housing variables as explanatory variables.

I perform the following experiment with the parameterized model of Section 4.2. I assume that country 1 experiences a housing shock while country 2 does not. I simulate a series of positive shocks in country 1 and obtain the reaction in both countries of the labor share in construction, the production of new houses and the trade balance from the steady state to the peak of the housing boom. For the current parameterization, this happens in the first period, i.e. in five years, because in the absence of frictions the country can build very quickly. To label the countries of Figure 2 as country 1 or country 2, I assume that positive housing movements in Figure 2 come from country 1. Negative movements come from country 2. This introduces a kink at zero in my simulation because, except for the trade balance, countries 1 and 2 do not react symmetrically to a country 1 shock, as shown in the lower right panel of Figure 6 . The asymmetry arises because labor is nontradable. Country 1 adjusts via two channels after the shock: it reallocates resources between its two sectors, and it runs a trade deficit, which implies resource reallocation in country 2 . These two channels are not symmetric because labor can only be reallocated domestically.

Figure 7 plots the results of the simulation. The top panel graphs the global imbalances predicted by the model for a series of shocks that trace out the observed movements in the labor share employed in construction between 1994 and 2006, as displayed on the horizontal axis. The middle panel follows the same procedure but matches the change in the value added by the construction sector observed in the data. The third panel matches the observed movements in the housing prices. In all the simulations, countries with positive housing movements are considered to be country 1 in the model. For both the value added and the labor share employed in construction, the model generates current account dynamics very similar to the observed global imbalances.

I interpret the previous result as evidence that, even if the model is too simple to be taken

as fully quantitative, the mechanism can help in explaining the correlation between housing and trade dynamics. The next section explores an alternative empirical approach. 

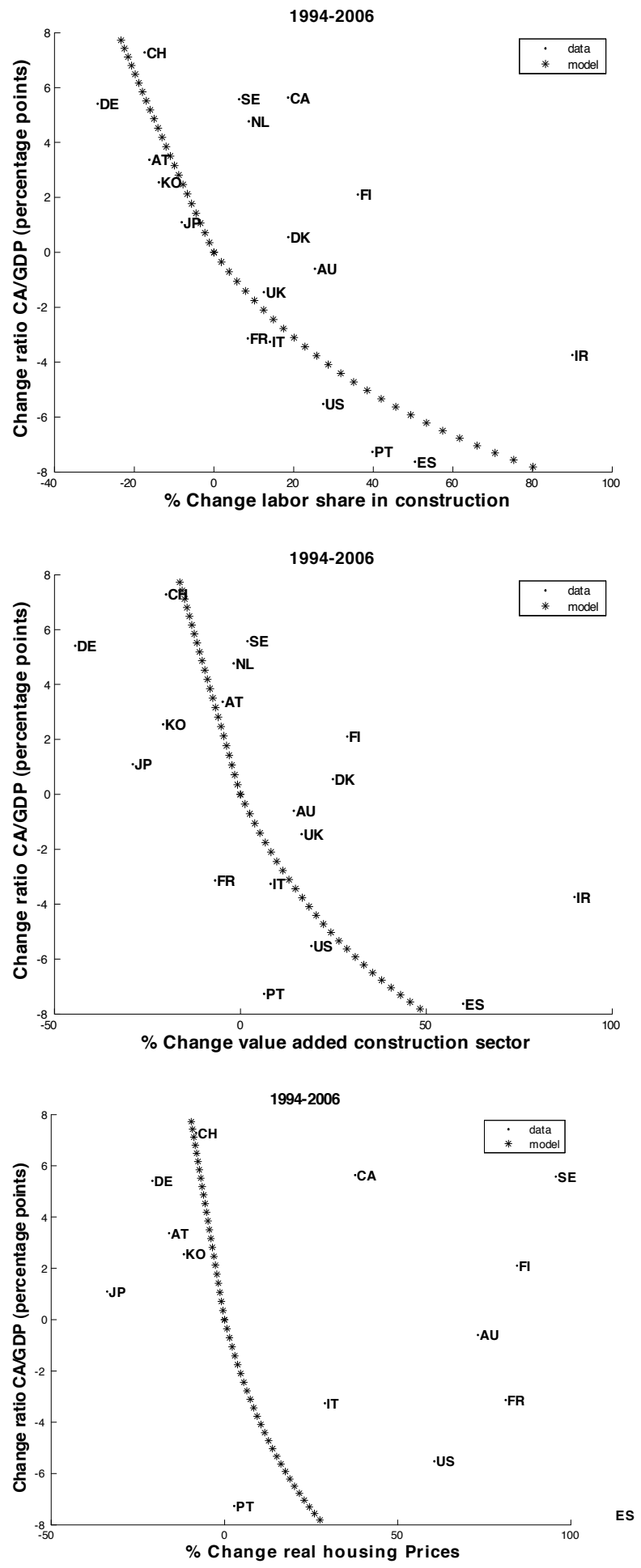

Fig. 7. Data and model-predicted global imbalances 


\section{Sign Restriction Identification}

This section exploits sign restrictions provided by the model in Section 4.2 to identify housing demand shocks and the mechanism described there from the forecast errors of a reduced form vector autoregression. I estimate two vector autoregressions: first using only the variables of the model in a sample of OECD economies. The results mostly confirm the mechanism. Second, I repeat the exercise for the U.S. and include the variables commonly used in the SVAR literature to identify other economic shocks. The results suggest that the mechanism may account for a non-trivial share of the variance of the trade balance forecasting error.

\subsection{Identification}

The model in Section 4.2 provides several sign restrictions summarized in Figure 6: conditional on a positive shock, the correlation between the shock, interest rates, housing prices, residential investment and employment in construction is positive. Moreover, the conditional correlation of the shock with tradable consumption is negative. Any model would predict that the increase in residential investment is positively correlated with an increase of employment in construction. But the other four sign restrictions differ both from those identifying shocks that do not originate in the housing sector, and from those of housing demand shocks which operate through collateral constraints or aggregate wealth effects. For example:

- Sector specific technology shocks do not imply increases in both house prices and quantities. A negative shock to the technology used to produce tradables may imply higher employment in construction, but the relative price of a house in terms of tradables would drop (producing tradables in now less efficient).

- Savings glut shocks or interest rate shocks (as risk premium shocks) would predict a negative correlation between interest rates, housing prices and quantities. In those models housing dynamics are caused by the interest rate shock, i.e. a drop in interest rates provokes an increase in housing demand. In this paper the causality is reversed: something else increases housing demand and this leads to higher interest rates to encourage the trade partner to finance the deficit.

- Neutral technology shocks or discount factor shocks (a standard way to generate aggregate wealth effects) do not generate negative comovement of housing and tradable consumption for several periods because if both housing and tradable consumption are normal goods then higher income, or higher impatience, increase households' demand for both goods, thus generating 
positive comovement (Aspachs-Bracons and Rabanal 2010b, Punzi 2008). In Section 4.2 of this paper the conditional correlation is negative, even if both housing and tradable consumption are normal goods, because of two effects that both push for lower tradable consumption. First, it is a relative demand shock (the higher demand for housing implies a lower demand for tradable goods). Second, housing is nontradable and labor is in fixed supply (the workers building houses are not producing tradables). For neutral technology shocks or impatience shocks these two effects work in opposite directions because the first one becomes positive (if the household is wealthier, or more impatient, and both goods are normal goods then she wants more consumption of both). What would not imply negative conditional comovement if the sign restrictions are imposed for a long enough number of periods. In fact, these shocks operating through the mechanism of this paper would generate a higher trade deficit than a relative demand shock would, because the household wants to increase tradable consumption while it is building houses (as shown in the upper left panel of Figure 6, with the relative demand shock the household just borrows to mitigate the consumption drop, not to increase tradable consumption).

\subsection{Methodology}

Faust (1998), Canova and De Nicoló (2002) and Uhlig (2005) have proposed different ways to impose sign restrictions directly on impulse responses to identify economic shocks in a structural vector autoregression (SVAR). I will follow Uhlig (2005), using an efficient algorithm proposed by Rubio-Ramirez et al. (2005) ${ }^{9}$.

I start by estimating a reduced form VAR which contains the four variables central for my identification: real final consumption $(C)$, employment in construction $\left(E_{h}\right)$, real long term interest rates $(L T R)$, real housing prices $\left(p_{h}\right)$ and the trade balance/GDP ratio $\left(\frac{N X}{G D P}\right)$. I estimate a VAR with four lags that I reformulate into the companion matrix VAR(1) form:

$$
Y_{t}=B Y_{t-1}+u_{t}
$$

\footnotetext{
${ }^{9}$ See Dedola and Neri (2007) for a recent survey of sign restriction identification and its advantages.
} 
where $E\left(u_{t} u_{t}^{\prime}\right) \equiv \Sigma$ and

$$
Y_{t} \equiv\left[\begin{array}{c}
\log C_{t} \\
\log E_{h_{t}} \\
L T R_{t} \\
\log p_{h_{t}} \\
\frac{N X_{t}}{G D P_{t}}
\end{array}\right]
$$

I assume that the forecast errors $\left(u_{t}\right)$ and the structural shocks $\left(\varepsilon_{t}\right)$ are related by

$$
u_{t}=A \varepsilon_{t}
$$

where $E\left(\varepsilon_{t} \varepsilon_{t}^{\prime}\right)=I$. This implies that $\Sigma=A A^{\prime}$. The impulse responses to the economic shocks are

$$
\frac{\partial Y_{t+j}}{\partial \varepsilon_{t}}=B^{j} A
$$

I want to identify the column of $A$ associated with the housing shock. Without loss of generality, I assume that the housing shock is the first entry in $\varepsilon_{t}$. Denoting the ith variable in $Y_{t}$ by $Y_{i t}$, I impose the following sign restrictions

$$
\frac{\partial Y_{1 t+j}}{\partial \varepsilon_{1 t}}<0, \frac{\partial Y_{2 t+j}}{\partial \varepsilon_{1 t}}>0, \frac{\partial Y_{3 t+j}}{\partial \varepsilon_{1 t}}>0, \frac{\partial Y_{4 t+j}}{\partial \varepsilon_{1 t}}>0
$$

where $j$ is the number of quarters during which I impose the sign restrictions. In the model the number of quarters during which the restrictions hold depends on the calibration. Hence I will compare the results using two different horizons, four and eight quarters. I do not impose any restriction on $\frac{N X_{t}}{G D P_{t}}$, since this is the variable of interest.

The matrix $A$ is unique up to an orthonormal transformation, i.e., wherever $Q Q^{\prime}=I$ then $\Sigma=A Q Q^{\prime} A^{\prime}$. I need to search for the set of $A Q$ matrices satisfying (24). I draw 1000 elements of that set. ${ }^{10}$

\subsection{Results}

My sample covers the period 1982:q1 to 2009:q4. Bems et al. (2007) provide several arguments for starting in 1982. First, we want the sample to cover a period when trade was

\footnotetext{
${ }^{10}$ I followed the algorithm of Rubio-Ramirez et al. (2005): without loss of generality, I assume $A=$ chol $(\Sigma)$, then I draw a matrix $X$, whose cells come from a standard normal distribution. Then I compute the QR decomposition of X. I normalize the diagonal of $\mathrm{R}$ to be positive and check if AQ satisfies (24). If it does, I keep $\mathrm{AQ}$, if not I discard and draw again. I keep drawing until I have 1000 successes.
} 
widely liberalized. Second, we also want to avoid both the structural break in monetary policy associated with the appointment of Paul Volcker (Clarida et al. 2000) and the structural break in the price of equipment reported by Fisher (2006). I estimate the VAR in levels of the logs of the variables (except for the interest rates and the ratio Net Exports/GDP for which I do not take logs). I do not model cointegration relationships, Sims et al. (1990) have shown that the system's dynamics can be consistently estimated in a VAR in levels even in the presence of unit roots. I also include a constant term.

Figures 8 and 9 report the range of impulse responses for the ratio Trade Balance/GDP to a positive housing shock. Figure 8 has the sign restrictions imposed for one year, Figure 9 for two. Sign restrictions are weak identification restrictions in the sense that they lead to a plurality of candidate structural impulse responses. Figures 8 and 9 plot the set of impulse responses satisfying the restrictions. The results in a sample of OECD economies mostly confirm that positive housing shocks imply a trade deficit through the consumption smoothing mechanism discussed in Sections 3 and 4.

\subsection{Quantitative importance}

To assess the quantitative importance of the mechanism I estimate a VAR that also includes the variables commonly used in the SVAR literature to identify other economic shocks: relative price of equipment $(p e)$, non farm business labor productivity $(z)$, total government fiscal deficit $(G)$, the price level $(P)$, and the Fed Funds rate $(F F)$. These are the variables used by Bems et al. (2007) to perform a horserace across different shocks identified with short and long run restrictions. They identify a fiscal shock, a neutral technology shock, an investment specific shock and a monetary shock. However, my methodology only identifies one shock, the housing shock. I study the same period (1982:q1 to 2006:q4) than Bems et al. (2007) and compare two 
proxies for tradable consumption: consumer durables and final consumption. Hence $Y_{t}$ is now

$$
Y_{t} \equiv\left[\begin{array}{c}
\log p e_{t} \\
\log z_{t} \\
G_{t} \\
\log P_{t} \\
F F_{t} \\
\log C_{t} \\
\log E_{h_{t}} \\
L T R_{t} \\
\log p_{h_{t}} \\
\frac{N X_{t}}{G D P_{t}}
\end{array}\right]
$$

and I impose the sign restrictions:

$$
\frac{\partial Y_{6 t+j}}{\partial \varepsilon_{1 t}}<0, \frac{\partial Y_{7 t+j}}{\partial \varepsilon_{1 t}}>0, \frac{\partial Y_{8 t+j}}{\partial \varepsilon_{1 t}}>0, \frac{\partial Y_{9 t+j}}{\partial \varepsilon_{1 t}}>0
$$

Figure 10 contains the impulse responses for the ratio Trade Balance/GDP to a positive housing shock. The first column has the sign restrictions imposed for one year, the second for two. The top row uses final consumption as a proxy for tradable goods. The bottom row uses consumer durables. The results are in line with Figures 8 and 9: a positive housing demand shock and the consumption smoothing mechanism imply a trade deficit.

Figure 11 computes the percentage of the variance of the trade balance forecasting error that is attributable to a positive housing shock. I report the results for the same two proxies of consumer tradables. The first column has the sign restrictions imposed for one year, the second for two. In Bems et al. (2007) fiscal and monetary shocks each account for around 10\% of the variance of changes in net trade/GDP at horizons of four and eight quarters, while neutral and investment specific shocks account for roughly 5\% each. Figure 11 shows that relative housing demand shocks through the mechanism of this paper may account for similar magnitudes.

\section{Concluding Remarks}

This paper makes a theoretical and an empirical contribution to the debate on what caused the global imbalances. I document that over the last decade there has been a strong crosscountry correlation between housing variables and current account dynamics. I present a simple 
model that shows that increases in the demand for nontradables relative to tradables imply trade deficits to smooth consumption between tradables and nontradables. I focus on housing, which I model as a durable nontradable good. Then I provide two types of evidence that this mechanism helps to explain recent global imbalances. A parameterized version of the model, for observed cross-section housing movements, generates trade balance dynamics consistent with recent OECD current account dynamics. Finally, housing demand shocks identified with model-consistent sign restrictions in a SVAR help to explain the trade balance in a sample of OECD economies. 

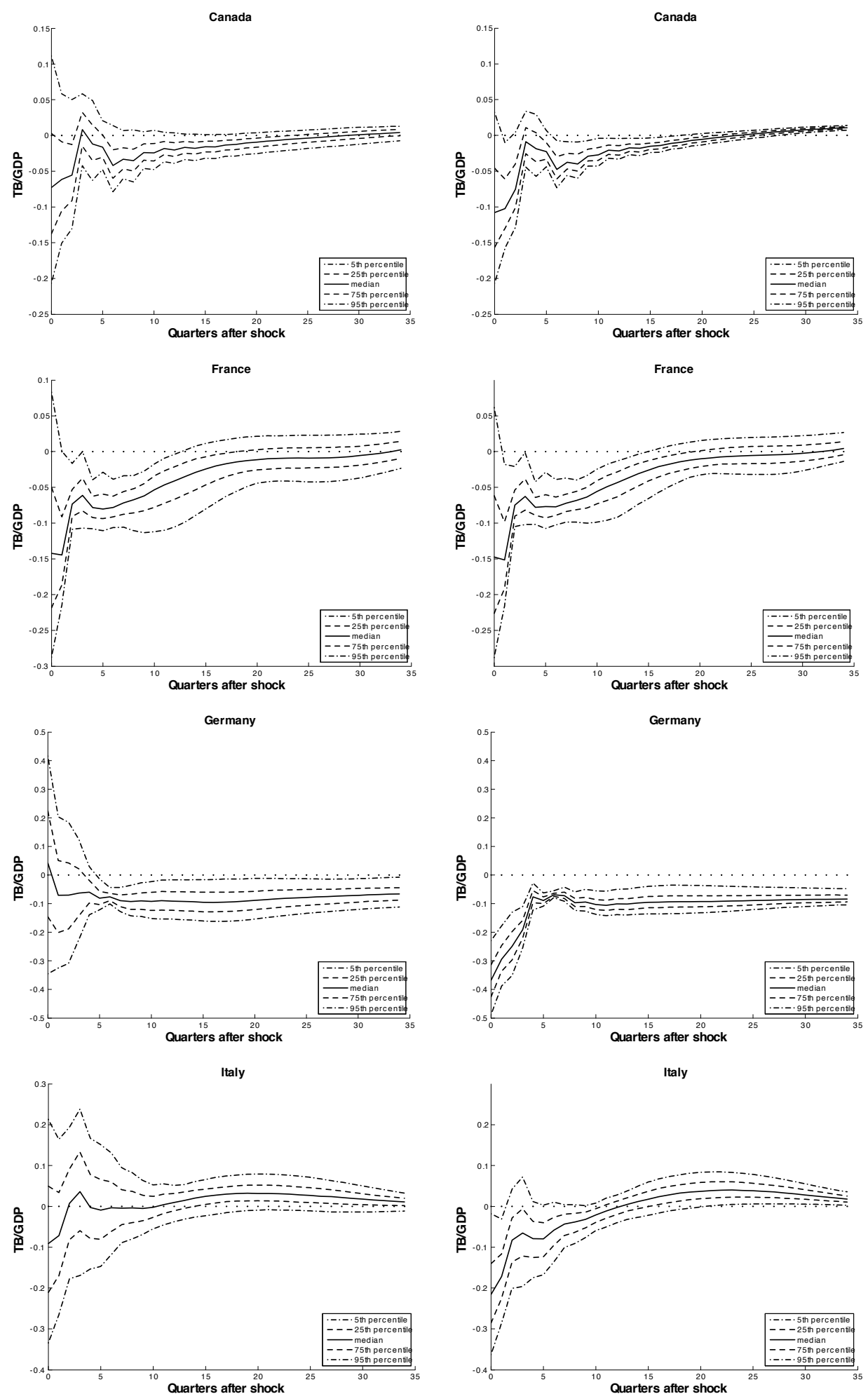

Fig. 8. Range of impulse responses for the ratio Trade Balance/GDP to a positive housing shock 

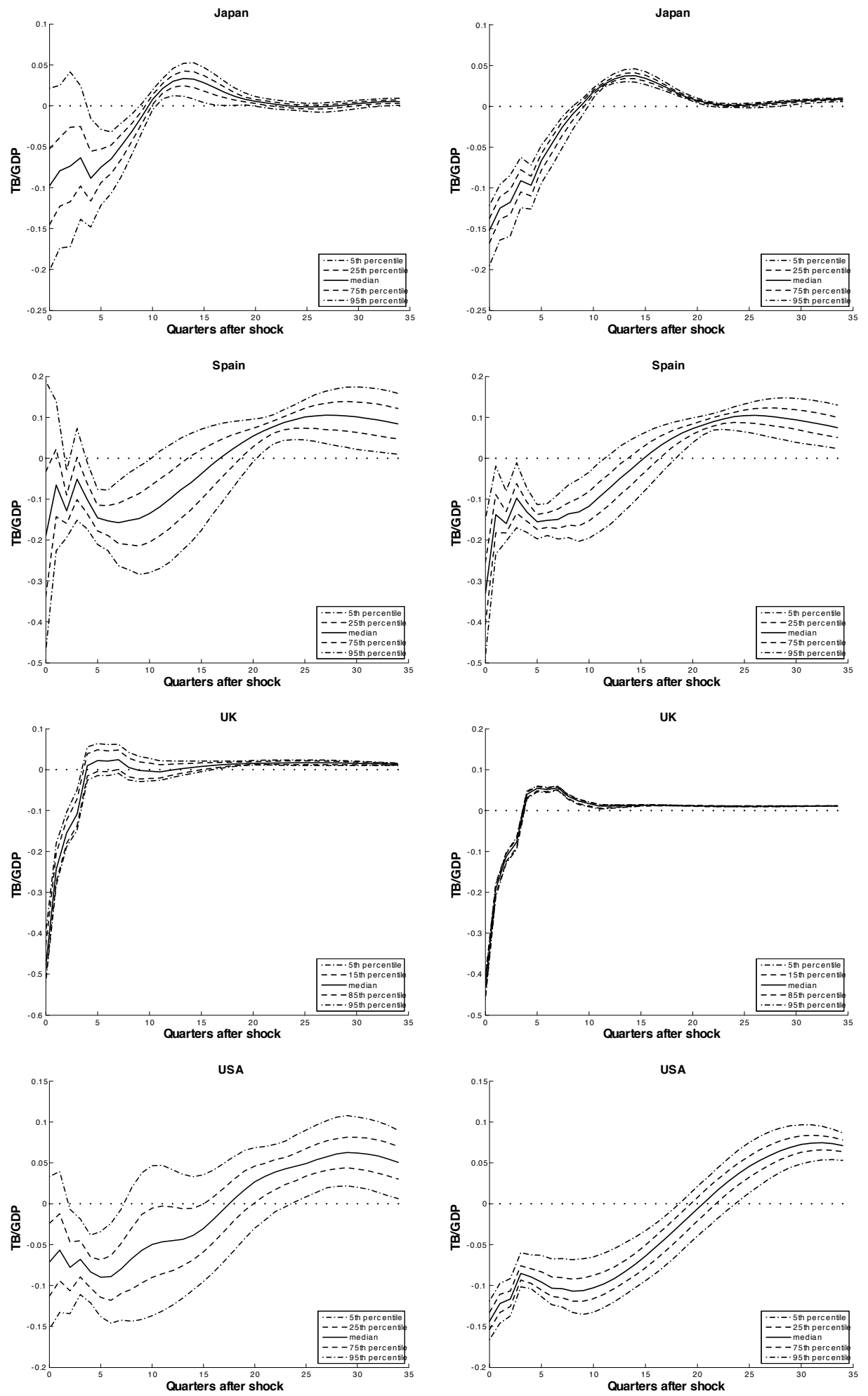

Fig. 9. Range of impulse responses for the ratio Trade Balance/GDP to a positive housing shock 

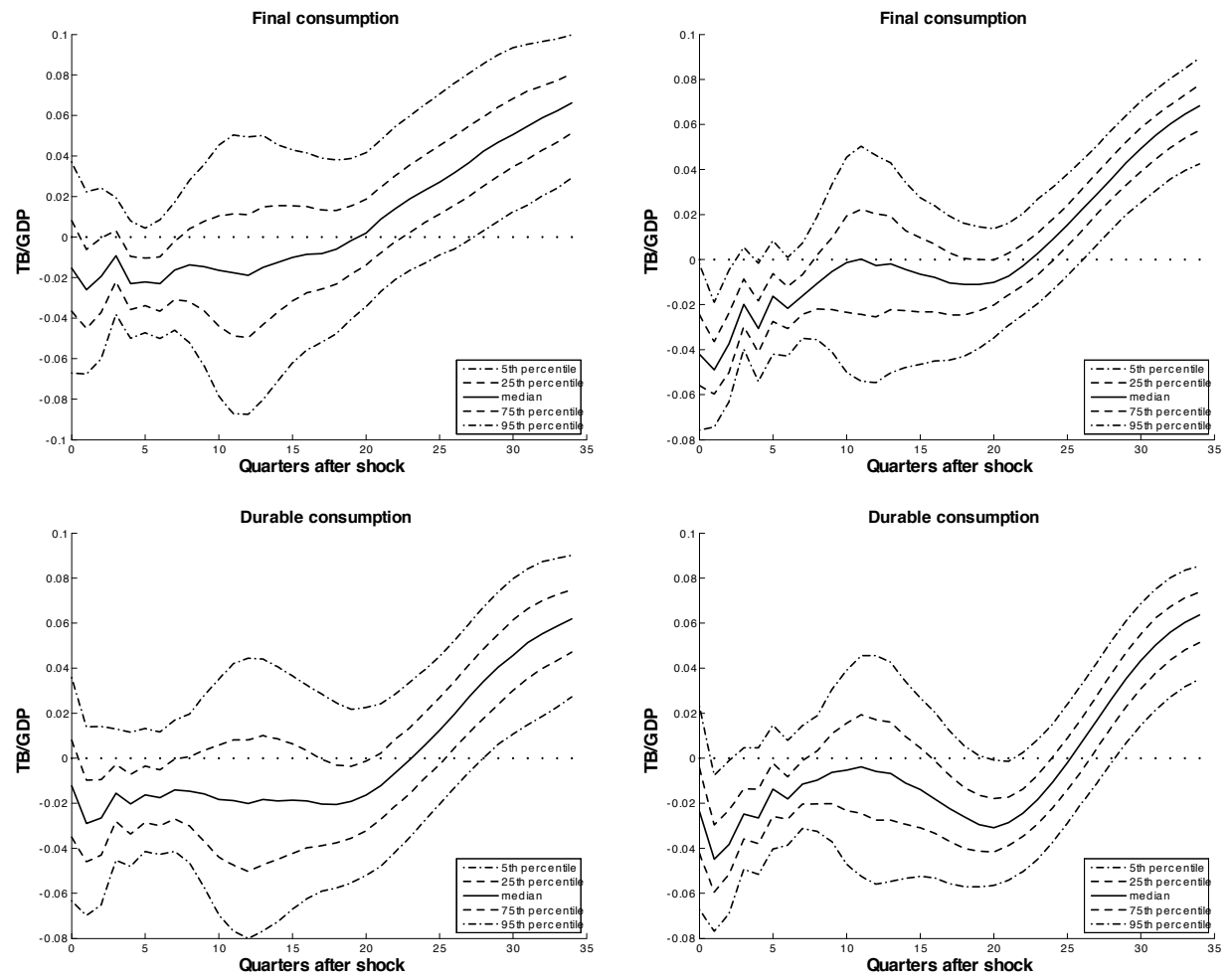

Fig. 10. Range of impulse responses for the U.S. ratio Trade Balance/GDP to a positive housing shock
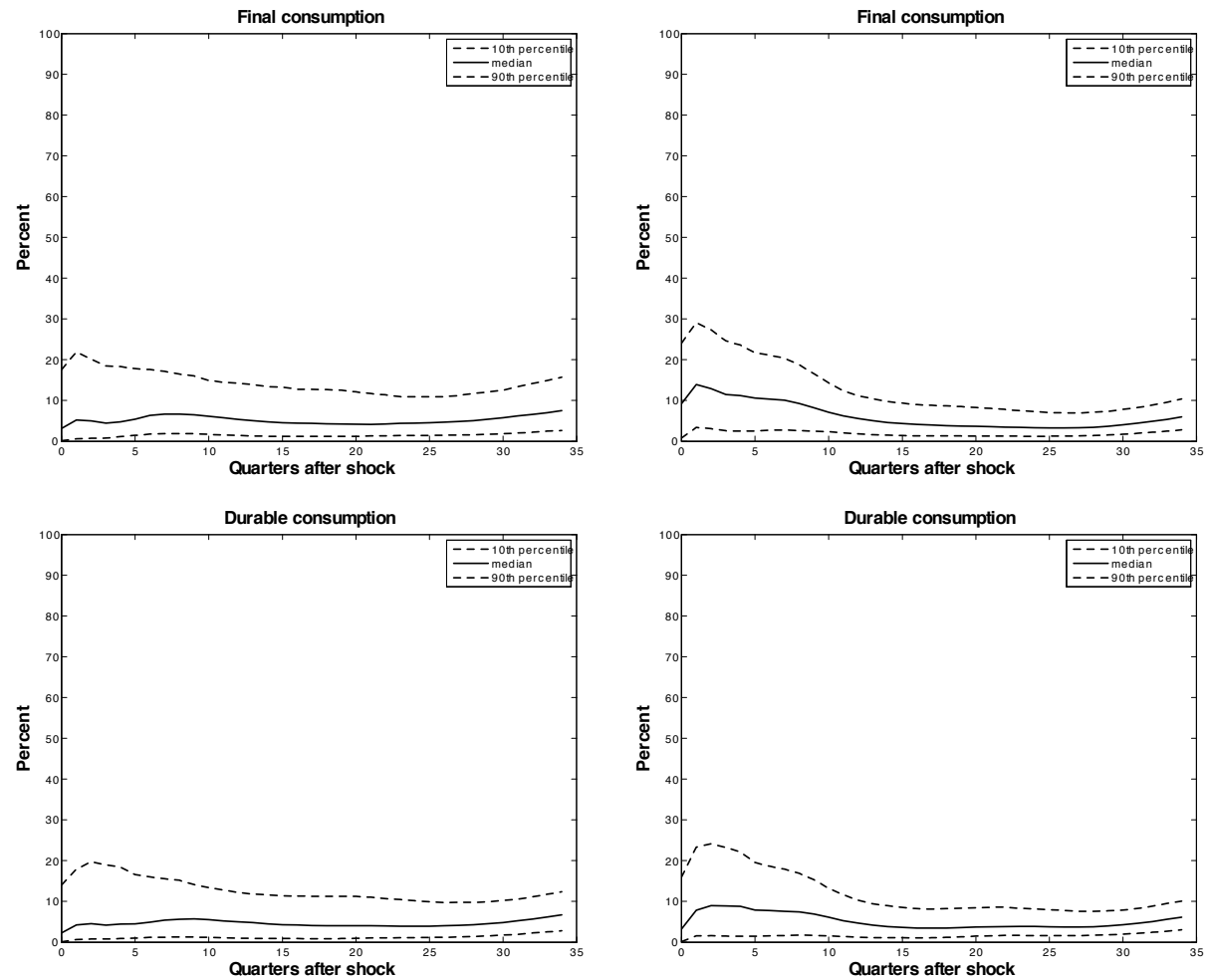

Fig. 11. Range of contribution of housing shocks to the U. S. variance of Trade Balance/GDP. 


\section{Data sources}

The series for current account and gross domestic product in Figures 1 and 2, and Table 1 are from the OECD. The series for labor share and value added from the construction sector are obtained from Datastream, which collects these data from domestic sources. The real house prices have been provided by the Bank of International Settlements and are compiled using national sources.

The series in Figure 3 for the trade balance in goods and its decomposition come from Table 2a in the U.S. International Transactions Accounts Data published by the BEA.

In Section 6, I used the series described in Bems et al. (2007) together with quarterly data on private final consumption, employment in the construction sector, 10 year constant maturity Government bond, CPI inflation, housing prices and the trade balance from the OECD and Datastream. The quarterly housing prices are described in Andre (2010). 


\section{References}

Aizenman, J. and Jinjarak, Y.: 2009, "Current Account Patterns and National Real Estate Markets", Journal of Urban Economics (66 (2)), 75-89.

André, C.: 2010, "A Bird's Eye View of OECD Housing Markets", OECD Economics Department Working Papers.

Aspachs-Bracons, O. and Rabanal, P.: 2010a, "The drivers of housing cycles in Spain", Journal of the Spanish Economic Association 1(1), 101-130.

Aspachs-Bracons, O. and Rabanal, P.: 2010b, "The Effects of Housing Prices and Monetary Policy in a Currency Union", International Journal of Central Banking .

Bems, R., Dedola, L. and Smets, F.: 2007, "US Imbalances: The Role of Technology and Policy", Journal of International Money and Finance (26 (4)), 523-545.

Buiter, W.: 2008, "Housing Wealth Isn't Wealth", NBER Working Paper No. W14204.

Bureau of Economic Analysis: 2004, BEA Depreciation Estimates.

Burstein, A., Neves, J. and Rebelo, S.: 2004, "Investment Prices and Exchange Rates: Some Basic Facts", Journal of the European Economic Association (2 (2-3)), 302-309.

Caballero, R., Farhi, E. and Gourinchas, P.: 2008, "Financial crash, commodity prices and global imbalances", Brookings Papers on Economic Activity (2) pp. 1-55.

Canova, F. and Nicoló, G.: 2002, "Monetary Disturbances Matter for Business Fluctuations in the G-7", Journal of Monetary Economics (49 (6)), 1131-1159.

Clarida, R., Gali, J. and Gertler, M.: 2000, "Monetary Policy Rules and Macroeconomic Stability: Evidence and Some Theory", Quarterly Journal of Economics (115 (1)), 147-180.

Congressional Budget Office: 2007, Housing Wealth and Consumer Spending.

Davidoff, T. and Yoshida, J.: 2008, "Reconciling Micro and Macro Estimates of Substitution Between Housing and Non-Housing Consumption by Relaxing Homotheticity Restriction".

Davis, M. and Heathcote, J.: 2005, "Housing and the Business Cycle", International Economic Review 46(3), 751-784.

Davis, M. and Ortalo-Magné, F.: 2010, "Household expenditures, wages, rents", Review of Economic Dynamics . 
Dedola, L. and Neri, S.: 2007, "What Does a Technology Shock Do? A VAR Analysis with Model-Based Sign Restrictions", Journal of Monetary Economics (54 (2)), 512-549.

Doms, M. and Krainer, J.: 2007, "Innovations in Mortgage Markets and Increased Spending on Housing", FRBSF working paper.

Eichengreen, B.: 2006, "The Blind Men and the Elephant".

Faust, J.: 1998, "The Robustness of Identified VAR Conclusions about Money". CarnegieRochester Series on Public Policy, 49, 207-244.

Fisher, J.: 2006, "The Dynamic Effects of Neutral and Investment-Specific Technology Shocks", Journal of Political Economy (114 (3)), 413-451.

Glaeser, E., Gottlieb, J. and Gyourko, J.: 2010, "Can interest rates explain the US housing boom and bust?", Vox. August 28th.

Gruber, J. and Kamin, S.: 2009, "Do Differences in Financial Development Explain the Global Pattern of Current Account Imbalances?", Review of International Economics (17 (4)), 667-688.

Guvenen, F.: 2006, "Reconciling conflicting evidence on the elasticity of intertemporal substitution: A macroeconomic perspective", Journal of Monetary Economics 53(7), 1451-1472.

Iacoviello, M.: 2005, "House Prices, Borrowing Constraints, and Monetary Policy in the Business Cycle", American Economic Review (95 (3)), 739-764.

Iacoviello, M. and Neri, S.: 2010, "Housing market spillovers: evidence from an estimated DSGE model", American Economic Journal: Macroeconomics 2(2), 125-164.

IMF: 2008, "Divergence of Current Account Balances across Emerging Economies", World Economic Outlook, Chapter 6 .

Kahn, J.: 2008, "What Drives Housing Prices?".

Kiyotaki, N., Michaelides, A. and Nikolov, K.: 2007, "Winners and Losers in Housing Markets".

Laibson, D. and Mollerstrom, J.: 2010, "Capital Flows, Consumption Booms and Asset Bubbles: A Behavioural Alternative to the Savings Glut Hypothesis", The Economic Journal $\mathbf{1 2 0}(544), 354-374$.

Matsuyama, K.: 1990, "Residential Investment and the Current Account", Journal of International Economics (28 (1)), 137-153. 
Mayer, C. and Hubbard, R.: 2008, "House Prices, Interest Rates, and Mortgage Market Meltdown".

Muellbauer, J.: 2007, "Housing, credit and consumer expenditure", Paper presented at the "Housing, Housing Finance, and Monetary Policy" Federal Reserve Bank of Kansas symposium, Jackson Hole, WY.

Piazzesi, M., Schneider, M. and Tuzel, S.: 2007, "Housing, consumption and asset pricing", Journal of Financial Economics 83(3), 531-569.

Punzi, M.: 2008, "Housing Market and Current Account Imbalances in the International Economy".

Roubini, N.: 2006, "Global Imbalances: a Contemporary Rashomon Tale".

Roubini, N.: 2006b, "The Contribution of Housing to Recent Employment Growth", Global EconoMonitor, September 4th.

Rubio-Ramirez, J., Waggoner, D. and Zha, T.: 2005, "Markov-Switching Structural Vector Autoregressions: Theory and Application".

Shin, H.: 2008, "Securitization, Subprime Mortgages and Global Imbalances", Briefing paper for the Academic Consultants Meeting, Federal Reserve Board.

Sims, C., Stock, J. and Watson, M.: 1990, "Inference in linear time series models with some unit roots", Econometrica (58 (1)), 113-144.

Tesar, L.: 1993, "International risk-sharing and non-traded goods", Journal of International Economics (35 (1-2)), 69-89.

The Economist: 2005, "A Home Grown problem", September 8th.

The Telegraph: 2008, "Foreign banks flee Spanish property debt", April 4th.

Uhlig, H.: 2005, "What are the effects of monetary policy on output? Results from an agnostic identification procedure", Journal of Monetary Economics (52 (2)), 381-419. 